\title{
Hastanede Yatan Kronik Obstrüktif Akciğer Hastalı̆̆ı Olan Bireylerde Dispne Şiddeti ve Genel Konfor Düzeyi Arasındaki İlişskinin Belirlenmesi
}

\author{
Cemile KÜTMEÇ YILMAZ *
}

\begin{abstract}
Öz
Giriș: Kronik obstrüktif akciğer hastalığı olan bireylerde en sık görülen semptom dispnedir. Şiddeti giderek artan dispne önemli fonksiyonel kısıtlllıklara yol açarak hastanın konforunu olumsuz yönde etkilemektedir. Amaç: Bu çalışma, hastanede yatan kronik obstrüktif akciğer hastalığı olan bireylerde dispne şiddeti ve genel konfor düzeyi arasındaki ilişkinin belirlenmesi amacı ile yapılmıştır. Yöntem: Tanımlayıcı ilişki arayıcı nitelikteki bu araştırma 20 Nisan - 20 Temmuz 2019 tarihleri arasında bir eğitim araştırma hastanesinin göğüs hastalıkları kliniklerinde yatan 158 hasta ile yapılmıştır. Araştırmanın verilerinin toplanmasında tanıtıcı bilgi formu, İngiliz Tıbbi Araştırma Konseyi Dispne Skalası, Dispne 12 Ölçeği ve Genel Konfor Ölçeği kullanılmıştır. İstatistiksel değerlendirmede sayı, yüzde, ortalama, standart sapma, Kruskall Wallis analizi, Spearman korelasyon testi kullanılmıştır. Bulgular: Çalışmada hastaların Dispne 12 Ölçeği ve Genel Konfor Ölçeği toplam puan ortalamalarının sırasıyla $25.91 \pm 8.63$ ve $2.59 \pm 0.36$ olduğu belirlenmiştir. Hastaların \%29.7'sinin orta şiddette, \%37.4'ünün şiddetli ve \%23.4'ünün çok şiddetli dispne yaşadığı saptanmıştır. Çalışmada, Genel Konfor Ölçeği toplam puan ortalamasına göre; hastaların medeni durumu, gelir durumu, evde oksijen kullanımı, hastaneye yatış, sıklığı, kullanılan ilaç, sayısı ve dispne şiddeti değişkenleri arasında istatistiksel olarak anlamlı bir fark olduğu belirlenmiştir $(p<0.05)$. Çalışmada, Dispne-12 Ölçeği ve Genel Konfor Ölçeği puan ortalamaları arasında negatif yönde zayıf yönde ve anlamlı bir korelasyon olduğu saptanmıştır ( $r=-.38 ; p=.000)$. Sonuç: Çalışmada dispne şiddeti arttıkça genel konfor düzeyinin azaldığı belirlenmiştir. Kronik obstrüktif akciğer hastalığı olan bireylere yönelik bütüncül bakım hizmeti sunumunda, dispne şiddetinin ve konforun değerlendirilerek dispnenin etkin yönetimine ve konforu arttırmaya yönelik hemşirelik girişimlerinin bakım planına eklenmesi önerilmektedir.
\end{abstract}

Anahtar Sözcükler: Dispne, Konfor, Kronik Obstrüktif Akciğer Hastalığı, Korelasyon.

\begin{abstract}
Determination of Correlation between the Severity of Dyspnea and General Comfort Level in Hospitalized COPD Patients

Background: Dyspnea is the most common symptom of COPD. Increasing severity of dyspnea causes significant functional limitations and negatively affects patient comfort. Objectives: The aim of study is to determine the correlation between the severity of dyspnea and general comfort level in hospitalized COPD patients. Methods: This descriptive, correlational study was conducted with 158 patients recruited in the chest diseases clinics of a training and research hospital between 20 April and 20 July 2019. Study data were collected by using an introductory information form, Medical Research Council Dyspnea Scale (MRC-DS), Dyspnea-12 Scale and General Comfort Questionnaire (GCQ). Data were analyzed using number, percentage, mean, standard deviation, Kruskall Wallis analysis, and Spearman correlation test. Results: Our study found that the total mean scores of patients were $25.91 \pm 8.63$ and $2.59 \pm 0.36$ for Dyspnea-12 Scale and GCQ respectively. $29.7 \%$ of patients had moderate dyspnea, $37.4 \%$ had severe dyspnea and $23.4 \%$ had very severe dyspnea. According to the total mean scores from GCQ; there was a statistically significant difference between the variables of patients' marital status, income level, use of oxygen at home, hospitalization frequency, number of medication and the severity of dyspnea $(\mathrm{p}<0.05)$. Our study also found that there was a negative, weak and significant correlation between Dispne-12 Scale and GCQ mean scores ( $r=-.38$; $p=.000)$. Conclusion: This study found that general comfort level decreased as the severity of dyspnea increased. Our suggestion is evaluating the severity of dyspnea and comfort and adding nursing interventions to the care plan in order to manage dyspnea effectively and increase comfort while providing holistic care service for COPD patients.
\end{abstract}

Key Words: Dyspnea, Comfort, Chronic Obstructive Pulmonary Disease, Correlation.

Geliş tarihi:21.01.2020

Kabul tarihi: 18.06.2020

$\mathrm{K}$ ronik obstrüktif akciğer hastalığı (KOAH), başta sigara olmak üzere zararlı gaz ve partiküllere maruziyet sonrası ortaya çıkan inflamatuvar sürece bağlı olarak gelişen ilerleyici hava akımı kısıtlaması ile karakterize sistemik etkili bir hastalıktır. KOAH aynı zamanda dünyada görülme sıklığı ve hastalık yükü giderek artan, önemli mortalite ve morbidite nedenleri arasında yer alan bir sağlık sorunudur. Dünyada ve ülkemizde ölüm nedenleri arasında 3. sırada KOAH yer almaktadır (1).

KOAH'ın neden olduğu fizyopatolojik değişiklikler sonucu dispne, yorgunluk, öksürük, balgam çıkarma, anksiyete, kas zayıflığı, kilo kaybı ve genel sağlıkta bozulma gibi birçok semptom ortaya çıkmaktadır (1). Hastalar tarafindan en sık deneyimlenen ve hastaların aktivite düzeyini önemli ölçüde kısıtlayan semptom dispnedir. Dispne, Amerikan Toraks Derneği (ATS) tarafından "niteliksel olarak çeşitli yoğunlukta duyuların oluşturduğu öznel solunum rahatsızlığı deneyimi" olarak tanımlanmaktadır (2). Tel Aydın ve ark. (2012) (3) tarafından yapılan çalışmada KOAH hastalarına dispne sırasında yaşadıkları duyguları sorulduğunda, "ölümden beter", "nefes alamadığım zaman kendimi yorgun, bitkin, yetersiz hissediyorum. Hayatım tamamen bitiyor", "nefesim daraldığı zaman Azrail geldi, öleceğim diye korkuyorum" şeklinde ifade etmişlerdir. Kısacası dispne subjektif bir deneyim olup, hastaların yoğun panik, korku ve anksiyete yaşamasına yol açan baş edilmesi güç bir yakınma olarak ifade edilmektedir $(3,4)$. Özellikle ileri evre KOAH hastalarında şiddetli dispne nedeni ile günlük yaşam aktivitelerinin de aşamalı olarak azaldığı (4) ve hastaların sosyal izolasyon yaşadığı belirtilmektedir (5). Günlük yaşam aktivitelerindeki sınırlılık ve hastalığa bağlı fonksiyonel kapasitenin giderek azalması, sosyal izolasyon yaşanması, bakım bağımlılı̆̆ının artmasına (6) ve yaşam kalitesinin düşmesine yol açmaktadır (7). Gökçek ve ark. (2019) (7) ve Chen ve ark. (2017) (8) KOAH hastalarında dispne, yorgunluk ve ağrının hastaların yaşam kalitesini olumsuz etkilediğini belirlemiş̧ir. $\mathrm{Bu}$ çalışma sonuçları göz önünde bulundurulduğunda, KOAH hastalarında dispne nedeni ile yaşanan fiziksel, sosyal, psikolojik, fonksiyonel kayıpların ve sorunların hastaların konforunu da olumsuz yönde etkileyebileceği öngörülmektedir.

* Cemile KÜTMEÇ YILMAZ, Dr. Öğretim Üyesi, Aksaray Üniversitesi Sağlık Bilimleri Fakültesi Hemşirelik Bölümü İç Hastalıkları Hemşireliği Anabilim Dalı, 68100, Aksaray. ORCID: 0000-0003-1827-5187, E-mail: cemilekutmec@yahoo.com, Tel: 038228827 71, Fax :+90382 288 27 99 
KOAH'ın ilerlemesi ile birlikte semptomların çoğunda özellikle dispne şiddetinde artışla birlikte tekrarlı hastane yatışları da artmaktadır (9). KOAH'lı bireylerde hastaneye yatışla birlikte ortamdan kaynaklanan fiziksel, çevresel ve psikolojik sorunlar konfor düzeyini etkileyebilmektedir. Özellikle klinik ve yoğun bakım ortamındaki gürültü, ses, 1şık gibi fiziksel özellikler, hastanın evinden, alışık olduğu ortamdan ayrılması, uygulanan tedavi ve bakıma ilişkin memnuniyet, hastalık ve süreç hakkında bilgilendirilme durumu, sağlık personeli ile etkin iletişim, geçmiş hastane deneyimleri gibi bir çok faktör hasta konforunu etkileyebilmektedir (10-12). Bu nedenle, özellikle tekrarlı hastane yatışı olan ve ciddi düzeyde dispne sorunu olan ileri evre KOAH hastalarında, konfor düzeyini değerlendirme ve geliştirmeye yönelik hemşirelik girişimlerinin uygulanması daha da önem kazanmaktadır.

Konfor kısaca bireyin rahatlığının sağlanması olarak ifade edilmekte ve bütüncül hemşirelik yaklaşımının vazgeçilmez unsurlarından birini oluşturmaktadır. Kolcaba konforu; "bireyin gereksinimlerine yönelik yardım etme, huzur sağlama ve sorunların üstesinden gelebilmeye ilişkin fiziksel, psikospiritüel, sosyal ve çevresel bütünlük içinde karmaşık bir yapıya sahip beklenen bir sonuç" olarak tanımlamakta ve "ferahlama, huzura kavuşma ve sorunların üstesinden gelebilmek için temel insan gereksinimlerini karşılamanın o andaki deneyimi” olarak ifade edilmektedir (13). Rahatsızlık yaratan durumların ortadan kaldırılması ya da etkisinin hafifletilmesi ile konfor sağlanabilir. Konforun hastaları güçlendirmeye yardımcı olduğu $(13,14)$ ve konfor düzeyi yüksek olan hastaların daha hızlı iyileştiği, hastalık sürecindeki stres ile daha iyi baş edebildiği belirtilmektedir $(14,15)$. Bu açıdan değerlendirildiğinde $\mathrm{KOAH}$ hastalarının hastalık semptomları ile etkin baş edebilmesi için konforun sağlanması ya da arttırılması büyük önem arz etmektedir. Bu durumda hastanede yatan KOAH hastalarında konforu etkileyen durumların belirlenmesi ve uygun girişimlerle hasta konforunun sağlanması, hemşirelik bakımının en temel amaçlarından biridir. Çünkü konfor gereksinimlerine odaklı sunulan hemşirelik girişimlerinin hasta memnuniyeti ve bakım kalitesi ile ilişkili olduğu düşünülmektedir (15). Fakat literatürde hastanede yatan KOAH hastalarında konforu, dispne şiddeti ile genel konfor arasındaki ilişkiyi değerlendiren bir çalışmaya rastlanmamıştır. Bu bakımdan hastanede yatan KOAH hastalarında dispne ve konfor düzeyi arasındaki ilişkinin belirlenmesi amacı ile yapılan bu çalışmanın literatüre katkı sunacağı düşünülmektedir.

\section{Araștırmanın Amacı}

$\mathrm{Bu}$ çalışmada, hastanede yatarak tedavi alan KOAH hastalarında dispne şiddeti ve genel konfor düzeyi arasındaki ilişkinin belirlenmesi amaçlanmıştır.

\section{Araştırmanın Soruları}

- Hastanede yatarak tedavi alan KOAH hastalarının dispne şiddeti nedir?

- Hastanede yatarak tedavi alan KOAH hastalarının genel konfor düzeyleri nedir?

- Hastanede yatarak tedavi alan KOAH hastalarının dispne şiddeti ile genel konfor düzeyi arasında ilişki var mıdır?

\section{Yöntem}

\section{Araştırmanın Tipi}

Tanımlayıcı - ilişki arayıcı nitelikte bir çalışmadır.

Araştırmanın Yapıldı̆̆ Yer

Araştırma 20 Nisan - 20 Temmuz 2019 tarihleri arasında İç Anadolu Bölgesi’nde bir eğitim araştırma hastanesinin göğüs hastalıkları kliniğinde yürütülmüştür.

\section{Araştırmanın Evreni/Örneklemi}

Bu araştırmanın evrenini, 20 Nisan - 20 Temmuz 2019 tarihleri arasında bir eğitim araştırma hastanesinin göğüs hastalıkları kliniğinde yatarak tedavi gören hastalar oluşturmuştur. Araştırmanın örneklemini, çalışmanın yürütüldüğü hastanenin göğüs hastalıkları kliniğinde yatarak tedavi gören ve KOAH tanısı alan 158 hasta oluşturmuştur. Araştırmanın örneklem büyüklüğü GPower V3.1.9.7 ile hesaplanmış ve korelasyon yaklaşımı kullanılmıştır. Buna göre iki ölçek arasında Cohen’in orta etki düzeyinde korelasyon olduğu durumda $(\rho=0.30), 0.80$ güçte $(1-\beta$ hata olasılığ $)$ ve 1 . tip hata 0.05 ( $\alpha$ hata olasılı̆̆ 1$)$ için ulaşılması gereken minimum örneklem büyüklüğü 84 kişi olarak hesaplanmıştır. Bu çalışmada ölçekler arası hesaplanan korelasyon düzeyi göz önüne alındığında $(\rho=0.380)$, 1. tip hata olasılığı $\alpha=0.05$ 'te, 158 örneklem ile tamamlanan araştırmanın post hoc gücü 0.998 olarak hesaplanmıştır. Çalışmada araştırmanın yapıldığı süre içerisinde araştırmanın yürütüldüğü kliniklerde yatarak tedavi gören, en az 6 ay önce KOAH tanısı almış, fiziksel ve bilişsel sağlık düzeyi araştırmada uygulanacak formları cevaplamaya uygun, iletişime engel bir sorunu olmayan ve araştırmaya katılmayı kabul eden tüm hastalar dahil edilmiştir.

\section{Veri Toplama Araçlart}

Araştırmanın verileri Tanıtıcı Özellikler Bilgi Formu, İngiliz Tıbbi Araştırma Konseyi (Medical Research Council, MRC) Dispne Skalası, Dispne 12 Ölçeği ve Genel Konfor Ölçeği (GKÖ) ile toplanmıştır.

Tanıtıcı Özellikler Bilgi Formu

Literatürdeki çalışmalar incelenerek geliştirilmiştir $(3,7,8)$. Bu form KOAH’ı olan hastaların sosyodemografik (yaş, cinsiyet, eğitim düzeyi, medeni durum, çalışma durumu, gelir durumu algısı, sigara içme durumu, 1sınma şekli) özellikleri ile tıbbi (KOAH dışındaki kronik hastalıkları, oksijen kullanımı, KOAH tanı süresi, kullanılan ilaç sayısı, hastaneye yatış sıklığı) özelliklerine ilişkin bilgileri içeren toplam 13 sorudan oluşmaktadır.

Ingiliz Tıbbi Araştırma Konseyi Dispne Skalası

Dispne hissi meydana getiren çeşitli fiziksel aktiviteler temel alınarak oluşturulan ve nefes darlığı algılamasına yoğunlaşan bir skaladır. İlk olarak Fletcher (1952) (16) tarafından, akciğer hastalığı olan ile olmayan bireylerin aktivite sırasındaki dispne şiddetlerini karşılaştırmak amacıyla kullanılan skala, dispnenin derecesini ölçmekte ve hastaların hastalığı algılayışı hakkında 
bilgi vermektedir. MRC Dispne Skalası uygulanırken, hastaların kendilerinde dispne oluşturan aktivite düzeyini belirtmeleri istenmektedir. Seçeneklerin puanlaması 0-4 arasındadır; 0 puan, dispne yok; 1 puan hafif dispne (düz yerde hızlı hareket ederken ve hafif yokuş çıkarken solunum sıkıntısı olması); 2 puan orta şiddette dispne (düz yerde yürürken yaşıtlarından daha yavaş yürümesi, soluklanmak için duraklaması); 3 puan şiddetli dispne (100 metre kadar veya birkaç dakika yürüyünce nefes almak için durması) ve 4 puan çok şiddetli dispne (evde günlük işlerini yaparken elbiselerini giyerken, çıkarırken veya tuvalete giderken nefessiz kalması) şeklinde puanlanmaktadır (17). Ölçeğin geçerlilik ve güvenilirlik çalışması yapılmamasına rağmen, yapılan çalışmalarda skalanın arteriyel kan gazı ve akciğer fonksiyon testleri ile ilişkili olduğu saptanmış ve ölçeğin dispne değerlendirilmesinde güvenle kullanılabileceği belirtilmiştir (17-19).

Dispne - 12 Ölçeği

Yorke et al (2010) (20) tarafından dispne (nefes darlığı) şiddetini ölçmek amacı ile geliştirilmiştir. Toplamda 12 maddeden oluşan ölçek, dörtlü likert tipteki ( $0=$ hiç, $1=$ hafif, $2=$ orta, $3=$ ciddi) seçenekleri içermektedir (20). Ölçeğin ilk yedi maddesi dispne nedeni ile hastaların yaşadığı fiziksel zorlukları değerlendirmekte ve bu kapsamda nefesin bütün akciğerlere gidip gitmediği, hastada nefes darlığının olup olmadığı, nefes almakta zorluk yaşanıp yaşanmadığı, nefes alırken çabanın var olup olmadığı sorgulanmaktadır. Ölçeğin kalan beş maddesi ise nefes almanın sinirlilik, stres, sıkıntı, huzursuzluk ve depresyon gibi duygusal durumlara etkisini değerlendirmektedir. Ölçeğin fiziksel boyutundan maksimum 21, duygusal boyutundan ise maksimum 15 puan alınabilmektedir. Ölçekten alınabilecek minimum puan 0, maksimum puan ise 36'dır. Ölçekten alınan puanın artması hastada dispne şiddetinin arttığını göstermektedir. Ölçeğin orijinal çalışmasında Cronbach alfa değeri .90 olarak bildirilmiştir. Ölçeğin ülkemiz için geçerlik ve güvenirlik çalışması Gök Metin ve Helvacı (2018) (21) tarafindan yapılmış olup, bu çalışmada ölçeğin Cronbach alfa değeri .97 olarak belirlenmiştir. Bu çalışmada ölçeğin Cronbach alfa değeri .93 olarak belirlenmiștir.

Genel Konfor Ölçeği (GKÖ)

Bireylerin konforla ilgili ihtiyaçlarını belirlemek, fiziksel rahatlığı ve refahı sağlamak veya iyileştirmek üzere planlanan hemşirelik uygulamalarını değerlendirmek için Kolcaba (1992) (13) tarafından geliştirilmiştir. Dörtlü likert tipte olan ölçek, 48 sorudan oluşmaktadır. Ölçekte konfor hem boyut hem de düzey olarak değerlendirilmektedir. Konfor boyut olarak; fiziksel (12 madde), psikospiritüel (13 madde), çevresel (13 madde) sosyokültürel boyutları (10 madde), düzey olarak ise; ferahlama (16 madde), rahatlama (17 madde) ve sorunların üstünden gelme (15 madde) boyutlarını içermektedir. Pozitif ve negatif maddelerden oluşan ölçeğin değerlendirilmesinde, negatif maddeler ters kodlanarak toplanmakta ve elde edilen toplam puan, maddelerin sayısına bölünerek ortalama değer bulunmaktadır. Ölçekten 1-4 aralığında bir ortalama değer elde edilmekte ve 1 düşük konforu, 4 ise yüksek konfor durumunu göstermektedir. Kolcaba tarafından konforun süreklilik özelliğinden çok durumluk özelliği gösterdiği ve konforun bütüncül yapısı nedeni ile ölçeğin bir bütün olarak değerlendirilmesinin daha doğru sonuçlar verdiği belirtilmiştir. Ölçeğin Türk toplumu için geçerlilik ve güvenilirlik çalışması Kuğuoğlu ve Karabacak (2008) tarafından yapılmış ve Cronbach's alpha değeri .85 olarak belirlenmiştir (22). Bu çalışmada ölçeğin Cronbach alfa değeri 0.83 'dir.

\section{Verilerin Değerlendirilmesi}

Araştırma verilerinin analizi IBM SPSS for Windows Version 21.0 (SPSS Inc. Chicago, IL, USA) paket programı kullanılarak yapılmıştır. Verilerinin analizinde; değişkenler yüzde, ortalama ve standart sapma ile özetlenmiştir. Normal dağılım göstermeyen araştırma verilerinde Man-Whitney U testi ve Kruskal Wallis testi, korelasyonu değerlendirmek için Spearman korelasyon analizi kullanılmıştır. Anlamlılık düzeyi $\mathrm{p}<.05$ olarak alınmıştır.

\section{Araştırmanın Etik Yönü}

$\mathrm{Bu}$ araştırma Helsinki Bildirgesi ilkelerine uygun olarak gerçekleştirilmiştir. Araştırmaya başlamadan önce Aksaray Üniversitesi İnsan Araştırmaları Etik Kurul'undan (19.04.2019 tarih ve 2019/03-52 sayılı karar) ve çalışmanın yürütüldüğ̈̈ kurumdan yazılı izin (12/03/2019 tarihli ve 66472688-900) alınmıştır. Ayrıca ölçeklerin kullanımı için ölçek geçerlik ve güvenirliğini yapan yazarlardan kullanım izni alınmıştır. Araştırmaya katılımda gönüllük esas alınmış ve araştırmacılar tarafından çalışma hakkında yapılan bilgilendirme sonrası hastaların onamları alınmıştır.

\section{Bulgular}

Tablo 1'de çalışmaya katılan hastaların sosyo-demografik ve hastalığa ilişkin özellikleri verilmiştir. Buna göre çalışmaya katılan KOAH hastalarının yaş ortalaması $72.82 \pm 9.35$ 'dir. Hastaların \%53.8'inin 73 yaş ve üzerinde, \%52.5'inin kadın olduğu ve \%44.3'ünün okur yazar olmadığı belirlenmiştir. Çalışmada hastaların tamamına yakınının evli olduğu, \%58.2'sinin emekli, \%65.8'inin gelirinin orta düzeyde olduğu, \%48.7'sinin sigara içmediği saptanmıştır. Hastaların KOAH'a ek olarak kronik hastalık varlığı sorgulandığında, \%67.1'inin HT, \%50’sinin DM, \%32.3’ünün kalp hastalığı olduğu belirlenmiştir. Hastaların \%29.7'si orta şiddette, \%37.4'ü şiddetli ve \%23.4'ü çok şiddetli dispne yaşadığını ifade etmiştir. 
Tablo 1. Hastaların Sosyo-demografik ve Hastalı̆̆a İlişkin Özellikleri $(n=158)$

\begin{tabular}{|c|c|c|}
\hline Değişkenler & $\mathbf{n}$ & $\%$ \\
\hline \multicolumn{3}{|l|}{ Yaş } \\
\hline$<73$ yaş & 73 & 46.2 \\
\hline 73 yaş ve üzeri & 85 & 53.8 \\
\hline \multicolumn{3}{|l|}{ Cinsiyet } \\
\hline Kadın & 75 & 47.5 \\
\hline Erkek & 83 & 52.5 \\
\hline \multicolumn{3}{|l|}{ Eğitim düzeyi } \\
\hline Okuryazar değil & 70 & 44.3 \\
\hline Okur yazar & 45 & 28.5 \\
\hline İlköğretim & 40 & 25.3 \\
\hline Lise & 3 & 1.9 \\
\hline \multicolumn{3}{|l|}{ Medeni durum } \\
\hline Evli & 154 & 97.5 \\
\hline Bekar & 4 & 2.5 \\
\hline \multicolumn{3}{|l|}{ Çalışma durumu } \\
\hline Çalışıyor & 2 & 1.4 \\
\hline Çalışmıyor & 64 & 40.4 \\
\hline Emekli & 92 & 58.2 \\
\hline \multicolumn{3}{|l|}{ Gelir durumu algısı } \\
\hline İyi & 7 & 4.5 \\
\hline Orta & 104 & 65.8 \\
\hline Kötü & 47 & 29.7 \\
\hline \multicolumn{3}{|l|}{ Sigara içme durumu } \\
\hline İçiyor & 10 & 6.4 \\
\hline İçmiyor & 77 & 48.7 \\
\hline Bırakmış & 71 & 44.9 \\
\hline \multicolumn{3}{|l|}{ Isınma şekli } \\
\hline Soba & 105 & 66.5 \\
\hline Kalorifer & 53 & 33.5 \\
\hline \multicolumn{3}{|c|}{ KOAH dışında mevcut kronik hastalıklar* } \\
\hline Hipertansiyon & 106 & 67.1 \\
\hline Diyabet & 79 & 50.0 \\
\hline Kalp yetmezliği & 51 & 32.3 \\
\hline \multicolumn{3}{|l|}{ Evde oksijen kullanımı } \\
\hline Evet & 104 & 65.8 \\
\hline Hayır & 54 & 34.2 \\
\hline \multicolumn{3}{|l|}{ KOAH süresi / yıl } \\
\hline$<11$ yil & 93 & 58.9 \\
\hline 11 yıl ve üzeri & 65 & 41.1 \\
\hline \multicolumn{3}{|c|}{ Sürekli kullanılan ilaç sayısı } \\
\hline 5 ve daha az & 95 & 60.1 \\
\hline 5'ten fazla & 63 & 39.9 \\
\hline \multicolumn{3}{|c|}{ Hastaneye yatış sayısı / yıl } \\
\hline 5 yatış ve altı & 109 & 69.0 \\
\hline 5 'in üzerinde yatış & 49 & 31.0 \\
\hline \multicolumn{3}{|l|}{ Dispne şiddeti } \\
\hline Hafif dispne & 14 & 9.5 \\
\hline Orta şiddette dispne & 47 & 29.7 \\
\hline Şiddetli dispne & 59 & 37.4 \\
\hline Çok şiddetli dispne & 37 & 23.4 \\
\hline
\end{tabular}

\footnotetext{
* n katlanmıştır.
} 
Araştırma

Tablo 2. Dispne 12 Ölçeği ve GKÖ Toplam Puan Ortalamaları

$\begin{array}{lc}\text { Dispne } 12 \text { Ölçeği } & \text { Ort } \pm \text { SS } \\ \text { Fiziksel boyut } & 15.20 \pm 5.03 \\ \text { Duygusal boyut } & 10.70 \pm 3.63 \\ \text { Dispne } 12 \text { Ölçeği toplam puan ortalaması } & 25.91 \pm 8.63 \\ \text { Genel Konfor Ölçeği toplam puan ortalaması } & 2.59 \pm 0.36\end{array}$

Ort.: ortalama, SS: standart sapma.

Çalışmaya katılan KOAH hastalarının Dispne 12 Ölçeği toplam puan ortalamasının $25.91 \pm 8.63$, fiziksel ve duygusal alt boyutları toplam puan ortalamasının $15.20 \pm 5.03$ ve $10.70 \pm 3.63$ olduğu belirlenmiştir. KOAH hastalarının GKÖ toplam puan ortalamasi $2.59 \pm 0.36$ 'dır (Tablo 2).

Tablo 3. Hastaların Bazı Özelliklerine Göre Dispne 12 Ölçeği ve GKÖ Toplam Puan Ortalamasının Karşılaştırılması (n = 158)

\begin{tabular}{|c|c|c|c|c|}
\hline \multirow[t]{2}{*}{ Değişkenler } & \multirow{2}{*}{$\begin{array}{l}\text { Dispne } 12 \\
\text { ölçeği } \\
\text { Ort } \pm \text { SS } \\
\end{array}$} & \multirow{2}{*}{$\begin{array}{l}\begin{array}{l}\text { İstatistiksel } \\
\text { değer }\end{array} \\
\mathbf{Z} / \mathbf{p} \\
\end{array}$} & \multirow{2}{*}{$\begin{array}{l}\text { GKÖ } \\
\text { Ort } \pm \text { SS }\end{array}$} & \multirow{2}{*}{$\begin{array}{l}\text { İstatistiksel değer } \\
\text { Z/p }\end{array}$} \\
\hline & & & & \\
\hline \multicolumn{5}{|l|}{ Yaş } \\
\hline 73 yaş altı & $24.52 \pm 9.03$ & $Z=1.794$ & $2.64 \pm 0.37$ & $\mathrm{Z}=1.310$ \\
\hline 73 ve üzeri & $27.10 \pm 7.87$ & .073 & $2.55 \pm 0.35$ & .190 \\
\hline \multicolumn{5}{|l|}{ Cinsiyet } \\
\hline Kadın & $24.78 \pm 8.59$ & $Z=1.522$ & $2.60 \pm 0.35$ & $Z=0.021$ \\
\hline Erkek & $26.92 \pm 8.59$ & .128 & $2.58 \pm 0.37$ & .983 \\
\hline \multicolumn{5}{|l|}{ Eğitim düzeyi } \\
\hline Okuryazar değil & $27.44 \pm 8.06$ & $\mathrm{KW}=3.843$ & $2.49 \pm 0.36$ & $\mathrm{KW}=12.243$ \\
\hline Okuryazar & $24.57 \pm 8.77$ & .428 & $2.61 \pm 0.33$ & .056 \\
\hline İlköğretim & $24.94 \pm 8.97$ & & $2.72 \pm 0.37$ & \\
\hline Lise & $25.00 \pm 1.73$ & & $2.84 \pm 0.10$ & \\
\hline \multicolumn{5}{|l|}{ Medeni durum } \\
\hline Evli & $25.80 \pm 8.66$ & $Z=0.290$ & $2.60 \pm 0.36$ & $Z=2.257$ \\
\hline Bekar & $28.00 \pm 6.92$ & .772 & $2.15 \pm 0.09$ & $.024 *$ \\
\hline \multicolumn{5}{|l|}{ Gelir durumu algısı } \\
\hline İyi & $22.57 \pm 10.50$ & $K W=1.105$ & $2.92 \pm 0.56$ & $K W=6.922$ \\
\hline Orta & $26.12 \pm 8.98$ & .576 & $2.61 \pm 0.35$ & $.031 *$ \\
\hline Kötü & $25.93 \pm 7.57$ & & $2.50 \pm 0.31$ & \\
\hline \multicolumn{5}{|l|}{ Sigara içme durumu } \\
\hline İçiyor & $24.30 \pm 5.81$ & $\mathrm{KW}=3.567$ & $2.34 \pm .023$ & $\mathrm{KW}=5.943$ \\
\hline İçmiyor & $24.88 \pm 8.91$ & .168 & $2.61 \pm 0.39$ & .051 \\
\hline Bırakmış & $27.25 \pm 8.55$ & & $2.60 \pm 0.33$ & \\
\hline \multicolumn{5}{|l|}{ Evde oksijen kullanımı } \\
\hline Evet & $28.45 \pm 7.93$ & $Z=5.066$ & $2.53 \pm 0.35$ & $Z=2.811$ \\
\hline Hayır & $21.01 \pm 7.82$ & $.000 *$ & $2.71 \pm 0.34$ & $.005 *$ \\
\hline \multicolumn{5}{|c|}{ KOAH tanısı alma süreniz/yıl } \\
\hline 11 y1ldan az & $23.95 \pm 8.44$ & $Z=3.682$ & $2.63 \pm 0.36$ & $Z=1.808$ \\
\hline 11 yıl ve üzeri & $28.70 \pm 8.16$ & $.000 *$ & $2.53 \pm 0.35$ & .071 \\
\hline \multicolumn{5}{|c|}{ Sürekli kullanılan ilaç sayısı } \\
\hline 5 ve daha az & $23.08 \pm 8.25$ & $Z=5.098$ & $2.67 \pm 0.35$ & $Z=3.522$ \\
\hline 5’ten fazla & $30.17 \pm 7.39$ & $.000 *$ & $2.46 \pm 0.33$ & .000 \\
\hline \multicolumn{5}{|c|}{ Yıllık hastaneye yatış sayısı } \\
\hline 5 yatış ve altı & $23.77 \pm 8.54$ & $Z=4.630$ & $2.68 \pm 0.33$ & $Z=4.445$ \\
\hline 5 'in üzerinde yatış & $30.65 \pm 6.80$ & $.000 *$ & $2.39 \pm 0.34$ & $.000 *$ \\
\hline \multicolumn{5}{|l|}{ Dispne şiddeti } \\
\hline Hafif dispne & $14.78 \pm 5.54$ & $K W=93.795$ & $2.95 \pm 0.29$ & $K W=30.334$ \\
\hline Orta şiddette dispne & $20.17 \pm 7.03$ & $.000 *$ & $2.71 \pm 0.33$ & $.000 *$ \\
\hline Şiddetli dispne & $27.37 \pm 5.03$ & & $2.54 \pm 0.26$ & \\
\hline Çok şiddetli dispne & $35.67 \pm 1.97$ & & $2.36 \pm 0.37$ & \\
\hline
\end{tabular}

GKÖ: Genel Konfor Ölçeği, Z: Mann Whitney U test, KW: Kruskal Wallis test,

$* \mathrm{p}<.05$ olarak kabul edilmiştir. 
Tablo 3'de çalışmaya katılan hastaların bazı demografik ve tıbbi özellikleri ile Dispne 12 ölçeği ve GKÖ toplam puan ortalamaları arasındaki karşılaştırmaya ilişkin veriler sunulmuştur. Çalışmada hastaların demografik ve tıbbi özellikleri ile Dispne 12 ölçeği toplam puan ortalaması karşılaştırıldığında, evde oksijen kullanımı $(\mathrm{p}=.000)$, KOAH hastalığının süresi ( $\mathrm{p}=$ $.000)$, sürekli kullanılan ilaç sayısı $(p=.000)$, bir yılda hastaneye yatış sayısı $(p=.000)$, dispne şiddeti $(p=.000)$ değişkenleri ile Dispne 12 ölçeği toplam puan ortalamaları arasındaki farklılığın istatistiksel olarak anlamlı olduğu belirlenmiştir (Tablo 3).

Hastaların bazı demografik ve tıbbi özellikleri ile GKÖ toplam puan ortalaması karşılaştırıldığında, yaş $(p=.190)$, cinsiyet $(p=.983)$, eğitim düzeyi $(p=.056)$, ssınma şekli $(p=.388)$, KOAH süresi $(p=.071)$ ve sigara içme $(p=.051)$ durumu değişkenleri ile GKÖ toplam puan ortalaması arasında istatistiksel olarak anlamlı bir fark olmadı̆̆ durum $(p=.024)$, gelir durumu $(p=.031)$, evde oksijen kullanımı $(p=.005)$, sürekli kullanılan ilaç sayısı $(p=.000)$, yıllık hastaneye yatış sayısı $(p=.000)$ ve dispne şiddeti $(p=.000)$ değişkenleri ile GKÖ toplam puan ortalaması arasında istatistiksel olarak anlamlı bir fark olduğu saptanmıştır (Tablo 3).

Tablo 4. KOAH Hastalarında Dispne Şiddeti İle Genel Konfor Düzeyi Arasındaki İlişki

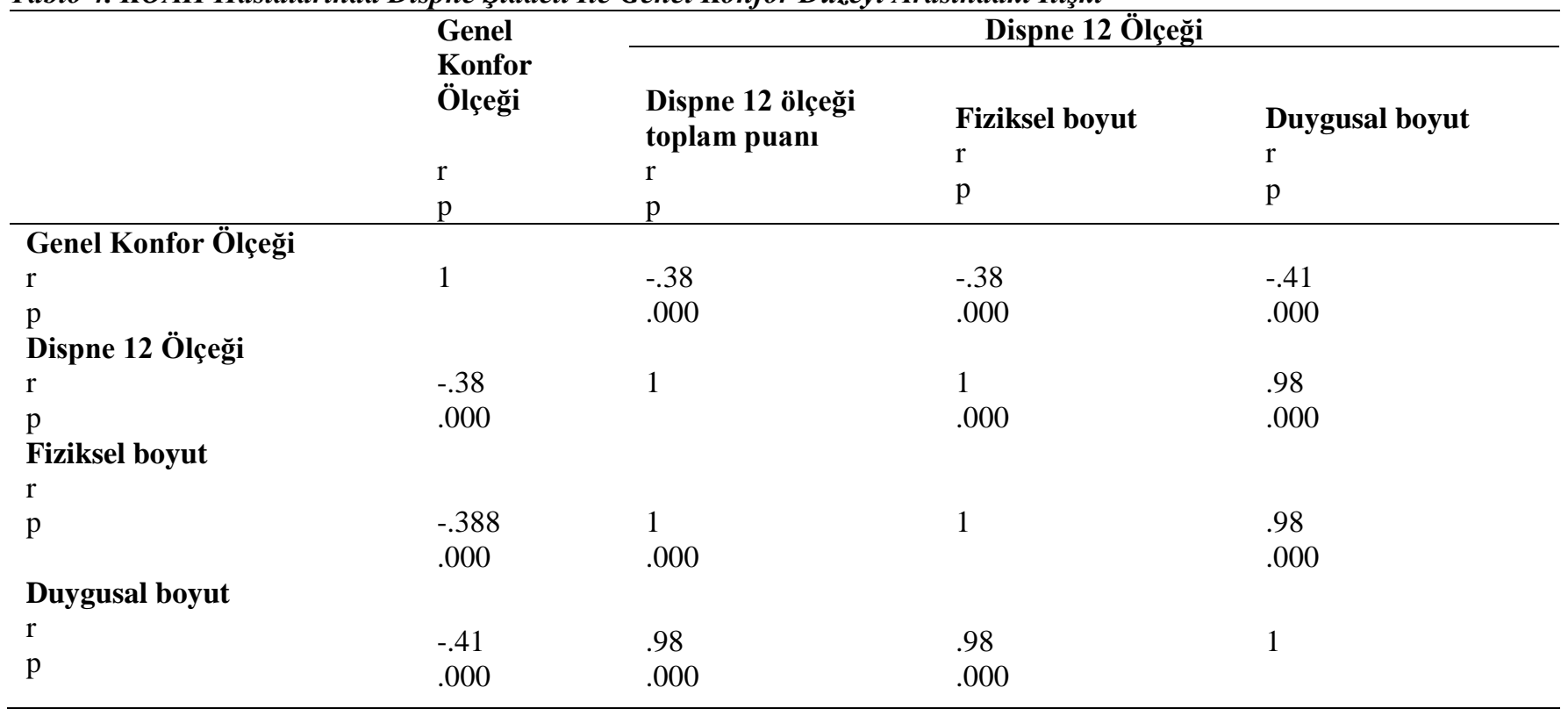

Tablo 4'de hastaların dispne şiddeti ile genel konfor düzeyi arasındaki ilişki verilmiştir. Çalışmada dispne şiddeti ile genel konfor düzeyi arasındaki ilişkiyi değerlendirmek için yapılan korelasyon analizinde, dispne şiddeti ile genel konfor düzeyi arasında negatif yönde istatistiksel olarak anlamlı zayıf bir ilişki saptanmıştır $(r=-.38 ; \mathrm{p}=.000)$. KOAH hastalarının dispne şiddeti arttıkça genel konfor düzeyi azalmaktadır (Tablo 4).

\section{Tartışma}

$\mathrm{Bu}$ çalışma hastanede yatan KOAH hastalarında dispne şiddeti ile genel konfor düzeyi arasındaki ilişkiyi belirlemek amacı ile yapılmıştır. Çalışmada KOAH hastalarının dispne şiddetinin ortalamanın üzerinde olduğu (25.91 \pm 8.63) ve KOAH tanı süresi 11 y1l ve üzerinde olan bireylerin dispne şiddetinin daha yüksek olduğu belirlenmiştir (Tablo 2). Benzer olarak Al-Gamal ve Yorke (2014) (23) tarafından yapılan çalışmada KOAH hastalarının dispne şiddetinin ortalamanın üzerinde olduğu (24.22 \pm 8.29) belirlenmiştir. Helvacı ve ark. (2019) (24) tarafından yapılan çalışmada KOAH hastalarının dispne şiddetinin orta düzeyde olduğu saptanmıştır. Yapılan bir diğer çalışmada KOAH hastalarında KOAH olmayanlara göre dispne şiddetinin daha yüksek olduğu belirlenmiştir (25). Çalışma sonuçlarımız bu sonuçlarla benzerlik göstermektedir. KOAH’ın ilerleyen evrelerinde dispne şiddeti giderek artmaktadır (23). Bununla birlikte, araştırmaya dahil edilen hastalarda dispne şiddetinin yüksek olmamasının hastaneye yatış ile birlikte hastalara başlanan oksijen desteği, inhaler ilaçlar ve noninvazif mekanik ventilasyon gibi tedaviler ve etkin şekilde sunulan hemşirelik girişimleri sonrası hastaların rahatlayabileceğinden kaynaklanabileceği düşünülmüştür.

Çalışmada hastalık yılı $(\mathrm{p}=.000)$, sürekli kullanılan ilaç sayısı $(\mathrm{p}=.000)$ ve yıllık hastaneye yatış sayısı $(p=.000)$ arttıkça dispne şiddetinin arttığı saptanmıştır (Tablo 3). Buna ek olarak evde oksijen kullanan hastaların dispne skorlarının daha yüksek olduğu belirlenmiştir. KOAH ilerleyici bir kronik hastalık olup, hastalık ilerledikçe semptom şiddeti ve akut alevlenme ataklarının sıklığı da artmaktadır (26). Bu nedenle özellikle ileri evre KOAH hastalarında dispne şiddetinin, kullanılan ilaç sayısının ve hastaneye başvuru sıklığının artması olasıdır. Yarkın ve ark. (2014) (27) tarafından KOAH süresi 10 yıldan fazla olan, komorbiditesi yüksek, evre 3 ve 4 KOAH'ı olan hastaların hastaneye yatış sıklığının daha fazla olduğu saptanmıştır. Sharma ve Sharma (2019) (2) tarafından yapılan çalışmada, hastalık yılı ve hastaneye yatış sıklığı fazla olan ve evde oksijen kullanan, komorbiditesi olan hastaların dispne skorlarının daha yüksek olduğu yani dispne şiddetinin arttığ belirlenmiştir. Ayrıca sürekli kullanılan ilaç sayısı fazla olan hastaların dispne skorlarının yüksek olması, KOAH'ın ileri 
evresinde ortaya çıkan komorbid durumlar nedeni ile mevcut tedaviye ek ilaç kullanımını gerektirmesi ile açıklanabilir. Bu sonuçlar çalışma bulgularımızla benzerlik göstermektedir.

Çalışmada hastaların konfor düzeyinin ortalamanın üzerinde olduğu belirlenmiştir (Tablo 2). Literatürde KOAH olan hastalarda konfor düzeyine yönelik yapılan herhangi bir çalışmaya rastlanmamıştır. Nural ve Alkan (2018) (12) tarafından koroner bakım ünitesinde yatan hastalar ile yapılan çalışmada hastaların GKÖ skorunun $3.22 \pm 0.33$ olduğu belirlenmiştir. Bir başka çalışmada gögüs cerrahisi uygulanan hastaların genel konfor skorunun $2.89 \pm 0.32$ olduğu bildirilmiştir (28). Bu sonuçlar çalışma bulgularımızla benzerlik göstermektedir. KOAH hastalarında görülen semptomların özellikle de dispnenin hastaların günlük aktivitelerinde, sosyal ilişkilerinde, spritüel gereksinimlerini karşılamada kısıtlılığa yol açması, sürekli ilaç kullanımı gerektirmesi ve oksijene bağımlı bir hayat sürmeyi zorunlu kılması hasta konforunu olumsuz yönde etkileyebilmektedir. Buna karşılık çalışmamızda hastaların konfor düzeyinin ortalamanın üzerinde olması, hastaneye yatış ile birlikte hastalara başlanan oksijen desteği, tıbbi tedavi ve etkin şekilde sunulan hemşirelik bakımı ile semptom şiddetinin azalması, hastaların hastane ortamında kendini güvende hissetmesi (11), olumlu hastane deneyimlerinin olması, hastalık hakkında yapılan bilgilendirmeler, sağlık çalışanları ile etkin iletişim kurma, kendisi gibi KOAH hastası olan bireylerle deneyimlerin paylaşılması gibi faktörlerin hasta konforuna olumlu yansıyabileceği düşünülmektedir (10).

Çalışmada evli olan hastaların genel konfor düzeyinin daha yüksek olduğu saptanmıştır (Tablo 3). Ören (2018) (28) tarafından yapılan çalışmada medeni durum ile genel konfor düzeyi arasında anlamlı bir ilişkinin olmadığı belirtilmiştir. Nural ve Alkan (2018) (12) evli olan hastaların genel konfor düzeyinin daha yüksek olduğunu fakat farkın istatistiksel olarak anlamlı olmadığını saptamıştır. Kuzulu ve ark. (2017) (5) tarafından yapılan çalışmada KOAH hastalarında hastalık evresi ilerledikçe aile, komşu ve arkadaş desteğinin giderek azaldığı belirlenmiştir. Başka bir çalışmada ise pozitif sosyal desteğin KOAH hastalarında hastaneye yatış sıklığında azalma, daha az alevlenme, daha iyi sağlık durumu ve hastalık yönetimi davranışlarında artma ile ilişkili olduğu bildirilmektedir (28). Sosyal desteğin genel konfor düzeyi üzerine etkili olduğu literatürde belirtilmektedir (29). Bu çalışma sonuçları dikkate alındığında evli olan bireylerde eşler tarafından sağlanan sosyal desteğin genel konfor düzeyinin iyileştirilmesine katkı sağladığı söylenebilir.

Gelir durumu arttıkça konfor düzeyinin arttığı saptanmıştır (Tablo 3). Cheng ve Wang (2014) (30) tarafından yapılan çalışmada gelir düzeyindeki artışa paralele olarak konfor düzeyinin arttığı belirlenmiştir. Başka bir çalışmada doğum sonu dönemdeki kadınlarda gelir durumunun artması ile psikospiritüel ve genel konforun arttığı belirlenmiştir (31). Konfor düzeyindeki artış, yüksek gelir düzeyi ile hastaların hastalık sürecinde ortaya çıkan gereksinimlerini karşılaması, KOAH'ın tedavisi için sunulan tüm tedavi olanaklarına ulaşabilme imkânı sunması ve hastalık sürecinde yaşanan ekonomik kayıplardan çok fazla etkilenmemesi ile açıklanabilir.

Çalışmada evde oksijen kullanan, sürekli olarak beşten fazla ilaç kullanan, yıllık yatış sayısı fazla ve dispne şiddeti yüksek olan hastaların konfor düzeyinin daha düşük olduğu saptanmıştır (Tablo 3). KOAH da hastalığın evresi ilerledikçe semptomların şiddetinde, hastaneye başvuru sıklığında ve kullanılan ilaç sayısında artış görülebilmektedir (2,27). Bu durum hastaların genel konforunun da olumsuz yönde etkilenmesine yol açabilir.

Konfor, hastalık ve hastalığa ilişkin algı, çevresel faktörler, sosyal, psikolojik, spiritüel ve iletişim gereksinimlerinin karşılanma durumu, kişisel deneyimler gibi birçok faktörden etkilenebilmektedir (15). Çalışmamızda hastaların Dispne 12 ölçeği toplam puan ortalaması ile GKÖ toplam puan ortalaması arasında negatif yönde istatistiksel olarak anlamlı zayıf bir ilişki olduğu, KOAH hastalarının dispne şiddeti arttıkça genel konfor düzeyinin azaldığı saptanmıştır (Tablo 4). Literatürde dispne ile genel konfor düzeyi arasındaki ilişkiyi inceleyen bir çalışmaya rastlanmamıştır. KOAH'da hastalığın ilerlemesi ile semptom şiddeti özellikle de dişpne şiddetinin artması önemli fonksiyonel kısıtlılıklara yol açmaktadır. Literatürde dispne şiddeti arttıkça yorgunluk (32), uykusuzluk (33), anksiyete, depresyon (7), günlük yaşam aktivitelerinde kısıtlanma (4), bakım bağımlılığı (6,34), yalnızlık, umutsuzluk (34) gibi sorunların ortaya çıktığı bildirilmektedir. Bunlara ek olarak dispne tekrarlı hastaneye yatışa, sosyal yaşamdan ve iş yaşamından çekilmeye (35), finansal güçlüklere (34), sosyal rolün değişmesine ve sosyal ilişkilerde sınırlılığa yol açabilmektedir $(3,34)$. Ayrıca dispneye bağlı yaşanan kısıtlılıkların hastaların dini inançlarının gereği olan bazı dini aktiviteleri yapma durumunu da olumsuz yönde etkilemesi olasıdır. Tüm bu sorunlar hastaların emosyonel değişiklikler yaşamasına ve kendilerine saygılarının ve güvenlerinin de azalmasına yol açabilmektedir (3). Dispneye bağlı yaşanan sorunlara baktığımızda, KOAH hastalarında dispnenin fiziksel, sosyo-kültürel, psikospritüel ve çevresel olarak hastayı çok yönlü etkileyebildiği görülmektedir. Buradan hareketle konforun bireyin fiziksel, psikospiritüel, sosyokültürel ve çevresel gereksinimlerinin karşılanması ile hissedilen iyi olma durumu olduğu göz önüne alındığında, dispnenin hastaların genel konfor düzeyini olumsuz yönde etkilemesi kaçınılmazdır. Bu nedenle ciddi düzeyde dispnesi olan KOAH hastalarında konfor düzeyinin değerlendirilmesi ve konforu arttırmaya yönelik girişimlerin uygulanması önem arz etmektedir. Konfor düzeyindeki artışın hastaların KOAH semptomları özellikle dispne ile baş etmesine katkı sağlayacağ düşünülmektedir $(14,15)$.

\section{Kisitlılıklar}

Araştırmada sınırlı sayıda örnekleme ulaşılması ve evrene genellenememesi ve anket formunda yer alan soruların hasta ifadelerine dayalı olması çalışmanın sınırlılıklarını oluşturmaktadır.

\section{Sonuçların Uygulamada Kullanımı}

Çalışmada KOAH hastalarında dispne şiddeti arttıkça genel konfor düzeyinin azaldığı saptanmıştır. Ayrıca medeni durum, gelir düzeyi, hastaneye yatış sayısı, kullanılan ilaç sayısı, evde oksijen kullanımı değişkenlerinin hasta konforu ile ilişkili olduğu belirlenmiştir. Bu sonuçlar doğrultusunda bütüncül bakım yaklaşımı sunan hemşireler tarafından KOAH hastalarında dispne şiddetinin ve genel konfor düzeyinin değerlendirilmesi önemlidir. Yapılan değerlendirme ile KOAH 
hastalarında dispne şiddetini azaltmaya ve hasta konforunu arttırmaya yönelik hemşirelik bakım girişimlerin planlanarak uygulanması önerilmektedir. Ayrıca hemşireler tarafindan KOAH hastası ve bakım verenlerine yönelik genel konforu etkileyen faktörler ve konforu arttırmaya yönelik girişimler konusunda bilgilendirme eğitimi yapılabilir. Ek olarak, bu çalışmanın tedavi ve bakımı evde sürdürülen KOAH hastalarının da dahil edildiği daha büyük örneklem gruplarında yapılması önerilmektedir.

\section{Bilgilendirme}

Yazar araştırmaya katılan KOAH hastalarına teşekkür etmektedir. Araştırmanın yapılabilmesi için Aksaray Üniversitesi İnsan Araştırmaları Etik Kurul'undan izin alınmıştır (Etik kurul karar tarihi: 19.04.2019 tarih ve karar numarası: 2019/03-52 sayılı karar).

Araştırmada herhangi bir çıkar çatışması yoktur. Araştırma ile ilgili herhangi bir projeden ya da firmadan destek alınmamıştır. Yazar tarafından herhangi bir çıkar çatışması bildirilmemektedir.

\section{Kaynaklar}

1. Global Strategy For The Diagnosis, Management And Prevention Of Chronic Obstructive Pulmonary Disease 2016. http://goldcopd.org/global-strategy-diagnosis-management-prevention-copd-2016/ Erişim:12.06.2019.

2. Sharma S, Sharma P. Prevalence of dyspnea and its associated factors in patients with chronic obstructive pulmonary disease. Indian Journal of Respiratory Care 2019;8:36-41.

3. Tel Aydın H, Tok Yıldız F, Karagözoğlu Ş, Özden D. Hastaların bakış açısıyla kronik obstrüktif akciğer hastalığı ile yaşamak: Fenomenolojik çalışma. İstanbul Üniversitesi FNJN 2012:20:177-183.

4. Çalık Kütükçü E, Arıkan H, Sağlam M, Vardar Yağlı N, İnal İnce D, Öksüz Ç ve ark. Kronik obstrüktif akciğer hastalarında çok boyutlu hastalık şiddeti ve günlük yaşam aktiviteleri arasındaki ilişkinin incelenmesi. Journal of Exercise Therapy and Rehabilitation 2015;2(2):53-60.

5. Kuzulu A, Bilgin G, Arslan İ, Öznur H, Kizıltaş Ö, Tekin O ve ark. KOAH hastalarında sosyal ilişkilerin değerlendirilmesi. Ankara Medical Journal 2017;(4):204-215.

6. Türk G, Üstün R. Kronik obstrüktif akciğer hastalığı (KOAH) olan bireylerin bakım bağımlılığının belirlenmesi. DEUHFED 2018;11(1):19-25.

7. Gökçek Ö, Hüzmeli ED, Katayıfçı N. Kronik obstrüktif akciğer hastalarında dispnenin yaşam kalitesi ve depresyona etkisi. Acıbadem Üniversitesi Sağlık Bilimleri Dergisi 2019;10(1):84-88.

8. Chen Z, Fan VS, Belza B, Pike K, Nguyen HQ. Association between social support and self-care behaviors in adults with chronic obstructive pulmonary disease. Ann Am Thorac Soc 2017;14(9):1419-1427.

9. Kırhan İ, Üzer F. Bir üniversite hastanesine KOAH alevlenme ile yatan hastaların genel özelliklerinin incelenmesi. Harran Üniversitesi Tıp Fakültesi Dergisi 2018;15(3):230-235.

10. Wensley C, Botti M, McKillop A, et al. Maximising comfort: how do patients describe the care that matters? A two-stage qualitative descriptive study to develop a quality improvement framework for comfort-related care in inpatient settings. BMJ Open 2020;10:e033336. doi:10.1136/bmjopen-2019-033336

11. Zengin N. Konfor Kuramı ve Yoğun Bakım Ünitesinin Hasta Konforuna Etkisi. Yoğun Bakım Hemşireliği Dergisi 2010;14(2):61-6.

12. Nural A, Alkan S. Identifying the factors affecting comfort and the comfort levels of patients hospitalized in the coronary care unit. Holist Nurs Pract 2018;32(1):35-42.

13. Kolcaba K. Holistic comfort: Operationalizing the construct as a nurse-sensitive outcome. ANS Adv Nurs Sci 1992;15(1):1-10.

14. Büyükünal Şahin P, Rızalar S. Ameliyat geçiren hastalarda konfor düzeyi ve etkileyen faktörlerin incelenmesi. HSP 2018;5(3):404-413.

15. Williams AM, Irurita VF. Emotional comfort: the patient's perspective of a therapeutic context. Int J Nurs Stud 2006;43:405-415.

16. Fletcher C. The Clinical Diagnosisof Pulmonary Emphysema: An Experimental Study. Proceedings of the Royal Society of Medicine 1952; 45 (9): 577-584.

17. Güneş ÜY, Kara D, Erbağcı A. Dispne yakınması olan hastalarda farklı dispne ölçeklerinin karşılaştırılması. DEUHFED 2012;(2): 65-71.

18. Kara D, Yıldız H. Dispne semptomunun değerlendirilmesinde dispne ölçeklerinin etkinlikleri ve kullanım sıklıkları. Gümüşhane Üniversitesi Sağlık Bilimleri Dergisi 2013;2(1).

19. Yürüktümen A, Karcıoğlu Ö, Topacoğlu H, Karbek F. Dispne ile başvuran geriatrik olgularda yakınma şiddeti ile klinik ve laboratuvar verilerinin değerlendirilmesi. Türkiye Acil Tıp Dergisi 2009;9(4):163-168.

20. Yorke J, Moosavi SH, ShuldhamC, Jones PW. Quantification of dyspnoea using descriptors: Development and initial testing of the Dyspnoea-12. Thorax. 2010;65:21-26.

21. Gök Metin Z, Helvacı A. Dispne-12 Ölçeğinin Türkçe geçerlik ve güvenirlik çalışması. HUHEMFAD 2018;5(2):102-115.

22. Kuğuoğlu S, Karabacak Ü. Genel Konfor Ölçeğinin Türkçe’ye uyarlanması. İstanbul Üniversitesi FNJN 2008;61(16):1623.

23. Al-Gamal E, Yorke J. Perceived breathlessness and psychological distress among patients with chronic obstructive pulmonary disease and their spouses. Nurs Health Sci. 2014;16(1):103-111. 
24. Helvacı A, Gök Metin Z, Özdemir L, Ergün P. The Effects of a nurse-led education and counseling program on dyspnea, health status, and care dependency in patients with chronic obstructive pulmonary disease: A feasibility study. Home Health Care Management \& Practice 2019:1-8. https://doi.org/10.1177/1084822319850819.

25. Tan JY, Yorke J, Harle A, Smith J, Blackhall F, Pilling M et al. Assessment of breathlessness in lung cancer: psychometric properties of the Dyspnea-12 Questionnaire. J Pain Symptom Manage 2017;53(2):208-215.

26. Miravitlles M, Ribera A. Understanding the impact of symptoms on the burden of COPD. Respiratory Research 2017;18:1-11.

27. Yarkın T, Ağca M, Acar G, Göl G, Tokgöz F, Baran R. Sık hastane yatışı olan KOAH hastalarında, komorbid faktörler ve aşırı dinamik hava yolu kollapsının yatış sıklığı ile ilgisinin araştırılması. Eurasian J Pulmonol 2014;16:169-174.

28. Ören B. Göğüs cerrahisi uygulanan hastaların konfor ve anksiyete düzeyini etkileyen faktörler. HSP 2018;5(3):324-332.

29. Dinicola G, Julian L, Gregorich SE, Blanc PD, Katz PP. The role of social support in anxiety for persons with COPD. J Psychosom Res 2013;74 (2):110-115.

30. Cheng F, Wang W. Factors influencing comfort level in head and neck neoplasm patients receiving radiotherapy. Int $\mathrm{J}$ Nurs Sci 2014;1(4):394-399.

31. Çapık A, Özkan H, Ejder Apay S. Loğusaların doğum sonu konfor düzeyleri ve etkileyen faktörlerin belirlenmesi. DEUHFED 2014;7(3):186-192.

32. Kütmeç Yılmaz C, Duru Aşiret G, Çetinkaya F, Kapucu S. Kronik obstrüktif akciğer hastalarında yorgunluğun günlük ve enstrümental yaşam aktiviteleri üzerine etkisi. Anadolu Hemşirelik ve Sağlık Bilimleri Dergisi 2017;20:2.

33. Dural G, Sarıtaş SÇ. Kronik obstrüktif akciğer hastalığı olan bireylerde uyku kalitesi ile anksiyete ve depresyon arasındaki ilişki. Acıbadem Üniversitesi Sağlık Bilimleri Dergisi 2019;10(2):247-252.

34. Janssen DJ, Wouters EF, Spruit MA. Psychosocial consequences of living with breathlessness due to advanced disease. Curr Opin Support Palliat Care. 2015;9(3):232-237. doi:10.1097/SPC.0000000000000146.

35. Kapısiz Ö, Eker F. Evaluation of the relationshipbetween the levels and perceptions of dyspnea and the levels of anxiety and depression in chronic obstructive pulmonary disease (COPD) patients. J Psychiatric Nurs 2018;9(2):88-95. DOI: 10.14744/phd.2018.53244 